\title{
The Option Pattern of Ngrasani (Gossiping) Code by Javanese Women in Social Interaction
}

\author{
Prembayun Miji Lestari \\ Linguistics Postgraduate Programme \\ Universitas Sebelas Maret \\ Jl. Ir. Sutami Surakarta, Indonesia \\ prembayun@student.uns.ac.id
}

\author{
Sumarlam \\ Faculty of Cultural Science \\ Universitas Sebelas Maret \\ Jl. Ir. Sutami Surakarta, Indonesia \\ sumarlam@staff.uns.ac.id
}

\author{
Djatmika \\ Faculty of Cultural Science \\ Universitas Sebelas Maret \\ Jl. Ir. Sutami Surakarta, Indonesia \\ djatmika@staff.uns.ac.id \\ Dwi Purnanto \\ Faculty of Cultural Science \\ Universitas Sebelas Maret \\ Jl. Ir. Sutami Surakarta, Indonesia \\ dwi.purnanto@yahoo.com
}

\begin{abstract}
The present study discusses the option pattern of ngrasani 'gossiping about someone' by rural and urban Javanese women when involved in social interaction called rewang 'taking part in other's event', arisan (a regular social gathering where a lottery is conducted), and positive relation among neighbours. The approach operative in the study is sociolinguistic in nature. The research site covers Klaten regency, Central Java, Indonesia. The data were collected by recording conversations among rural and urban Javanese women when they ngrasani (gossiped) about someone in the very social interactions. The research findings reveal that the code options comprised of Bahasa Jawa Ngoko (casual Javanese language), Bahasa Jawa Krama (formal Javanese language), the combination of Ngoko and Krama language, and the combination of Javanese language and Indonesian or even foreign language. The code options used by Javanese women when gossiping about someone envinces that the higher a woman's social and education class was, the more varied code options she used. By contrast, the lower a woman's social and education class was, the fewer code options she used. Also, the younger she was, the more varied her language would be. These findings corroborate that correlation is evident between the language a woman speaks and her habits, which are different across ages and education levels.
\end{abstract}

Keywords - code option patterns; ngrasani 'gossiping about someone'; rural Javanese women; urban Javanese women; social interaction

\section{INTRODUCTION}

The patterns of code choice become an interesting study in Sociolinguistics because it is not only related to language spoken among interlocutors but also related to socio-cultural society. Different ethnic has different patterns of code choice (Chuchu \& Noorashid, 2015). Javanese women, henceforth $\mathrm{JW}$, during gossiping in rewang, arisan, and neighborhood activities, use certain choices of code to communicate with others. Who is speaking, with whom the speech is done, what language is being spoken, when a speech takes place, and what a conversation is about are all driving components which influence the choices of code. The choices of code used by rural Javanese women (RJW) and urban Javanese women (UJW) during gossiping in rewang, arisan, and neighborhood activities vary from one situation to another.

\section{LITERATURE REVIEW}

Code is speech system used to conduct communication between two or more speakers, which can be represented by either a dialect or a specific language (Wardhaugh, 1986). Kridalaksana (2008, p. 127) defines code as (1) the symbol or phrase system used to describe a particular meaning; human language is a kind of code; (2) the language system in a society; and (3) certain variations in a language.

In a verbal interaction a $\mathrm{P}$ can shift from one language to another. Crystal (1987, pp. 362-363) refers to the phenomenon as language mixing, language switching, or code switching. Code mixing is the mixture of language characterized by the use of certain expressions or short phrases in speech. Hudson (1996, p. 53) states that "in code switching the point of which languages change corresponds to a point where the situation changes, either on its own or precisely because the language changes". Sumarsono (2004) contends that when a speaker consciously uses other language elements while speaking in a language, then this phenomenon denotes code mixing. In this study, code mixing is found in JW's interactions when gossiping.

The studies of codes have been conducted by Chuchu \& Noorashid (2015) who examine inter-ethnic minority code choices in Brunei. In the same vein, Jaafar, Beginning, Mis, \& Lateh (2016) probe the code choices used by communities in Malaysia and Thailand, particularly on domains concerning businesses and families. da Silva (2017) discusses the choice of codes on non-commercial billboards. Alagappar, Dealwis, David (2018) delve into the codes of minority immigrants in Tamil, Kuching, Sarawak Malaysia, focusing on home and 
friendship domains. These studies at least shed light on how the choices of code are used by certain communities. The previous studies reveal that although many have investigated the choices of code, but different focuses lie on the research problem, the subjects under investigation, and the methodology operative in each study. With these differences, different findings have obviously been garnered. Based on the voluminous body of previous studies on the choices of code, choices of code operative in gossiping among Javanese women in rewang, arisan, and neighbour activity have been underresearched. Previous studies on code mixing are used as references for the author to delve into the issue deeper.

\section{METHOD}

The present study is qualitative in nature because one of its characteristics deals with generating description, as stipulated by the research objective. This research employs two approaches, namely theoretical and methodological approaches. From theoretical perspective, the study applies sociolinguistic approach, and from methodological spectacle the study employs Ethnography. The reseach site was rural areas in Montelan village, Sidorejo village, Tibayan village, Klaten regency, urban area in Gergunung Regional Housing II, Northern Klaten, and Klaten Regency. The primary data of the study were derived from the use of Javanese language (JL) in gossiping by JW in their social interactions, including rewang, arisan, and neighborhood activities. Another pertinent primary data were btained from informant, which focused on data within a particular sociocultural context. The secondary data of the research were data related to the research focus. The data were collected by observation. The data analysis technique operated was interactive analysis model developed by Miles and Huberman (in Sutopo, 2006, pp. 113-116; Mahsun 2007, p. 270), comprising 1), data reduction, 2) data presentation, and 3) drawing conclusion and verification.

\section{RESULT AND DISCUSSION}

The selection of codes found in the study has portrayed JW's habits in using codes during gossiping. It is these choices of codes which portray how social dialects vary within a particular area. This finding is in line with Labov's research findings (in Sumarsono, 2014, p. 50); Jaafar, Beginning, Mis, and Lateh (2016) revealing that a particular individual or society belonging to a particular social class or a particular sex group will use a certain form of code variations under certain circumstances.

The choices of code used by JW during gossiping in social interactions of rewang activities evince that the higher a woman's social class is, the more varied the codes she uses. Conversely, the lower the social status of a woman is, the less varied the codes she employs. The results of empirical data analysis explicates that elder or low educated JW tend to choose a single code, while young or highly educated JW tend to use code mixing (CM) to communicate during gossiping.

TABLE I. THE PATTERNS OF CODE CHOICES IN GOSSIPPING AMONG RJW IN SOCIAL INTERACTIONS

\begin{tabular}{|c|c|c|c|}
\hline Area & Sub- & P-MT & Code Choices \\
\hline
\end{tabular}

\begin{tabular}{|c|c|c|c|c|c|c|c|c|}
\hline & \multirow[t]{2}{*}{ domain } & \multirow{2}{*}{$\begin{array}{c}\text { Based on } \\
\text { Age and } \\
\text { Education } \\
\text { Level }\end{array}$} & \multicolumn{3}{|c|}{$J L$} & \multirow[b]{2}{*}{$\begin{array}{l}I \\
L\end{array}$} & \multirow[b]{2}{*}{$\begin{array}{l}F \\
L\end{array}$} & \multirow[b]{2}{*}{$C M$} \\
\hline & & & $\begin{array}{c}C J \\
L\end{array}$ & $\begin{array}{c}F J \\
L\end{array}$ & $\begin{array}{c}C J \\
L \\
+ \\
F J \\
L\end{array}$ & & & \\
\hline \multirow{16}{*}{$\begin{array}{l}\text { Rural } \\
\text { area }\end{array}$} & \multirow[t]{2}{*}{ Rewang } & $\begin{array}{l}\text { Young } \\
\text { speaker- } \\
\text { young } \\
\text { speaker }\end{array}$ & $\sqrt{ }$ & - & - & - & - & \\
\hline & & $\begin{array}{l}\text { Young } \\
\text { speaker- } \\
\text { Elder } \\
\text { speaker }\end{array}$ & - & - & $\sqrt{ }$ & - & - & $\begin{array}{c}\mathrm{CJL}+\mathrm{FJ} \\
\mathrm{L}+\mathrm{IL}\end{array}$ \\
\hline & & $\begin{array}{l}\text { Elder } \\
\text { speaker- } \\
\text { Elder } \\
\text { speaker }\end{array}$ & $\sqrt{ }$ & - & - & - & - & \\
\hline & & $\begin{array}{l}\text { Low } \\
\text { education } \\
\text {-High } \\
\text { education }\end{array}$ & - & - & - & - & - & \\
\hline & & $\begin{array}{l}\text { High } \\
\text { education } \\
\text {-High } \\
\text { education }\end{array}$ & - & - & $\sqrt{ }$ & - & - & $\begin{array}{c}\text { CJL+FJ } \\
\mathrm{L}+\mathrm{IL} \\
\mathrm{CJL}+\mathrm{FJ} \\
\mathrm{L}+\mathrm{IL}+\mathrm{F} \\
\mathrm{L}\end{array}$ \\
\hline & & $\begin{array}{l}\text { Low } \\
\text { education } \\
\text {-Low } \\
\text { education }\end{array}$ & $\sqrt{ }$ & - & - & - & - & \\
\hline & Arisan & $\begin{array}{l}\text { Young } \\
\text { speaker- } \\
\text { young } \\
\text { speaker }\end{array}$ & $\sqrt{ }$ & - & - & - & - & $\begin{array}{c}\mathrm{CJL}+\mathrm{FJ} \\
\mathrm{L}+\mathrm{IL}\end{array}$ \\
\hline & & $\begin{array}{l}\text { Young } \\
\text { speaker- } \\
\text { Elder } \\
\text { speaker }\end{array}$ & $\sqrt{ }$ & - & $\sqrt{ }$ & - & - & \\
\hline & & $\begin{array}{l}\text { Elder } \\
\text { speaker- } \\
\text { Elder } \\
\text { speaker }\end{array}$ & $\sqrt{ }$ & - & - & - & - & \\
\hline & & $\begin{array}{l}\text { Low } \\
\text { education } \\
\text {-High } \\
\text { education }\end{array}$ & - & - & $\sqrt{ }$ & - & - & $\begin{array}{c}\mathrm{CJL}+\mathrm{FJ} \\
\mathrm{L}+\mathrm{IL}\end{array}$ \\
\hline & & $\begin{array}{l}\text { High } \\
\text { education } \\
\text {-High } \\
\text { education }\end{array}$ & - & - & - & - & - & $\begin{array}{c}\mathrm{CJL}+\mathrm{FJ} \\
\mathrm{L}+\mathrm{IL}\end{array}$ \\
\hline & & $\begin{array}{l}\text { Low } \\
\text { education } \\
\text {-Low } \\
\text { education }\end{array}$ & $\sqrt{ }$ & - & - & - & - & \\
\hline & $\begin{array}{l}\text { Neighbo } \\
\text { orhood } \\
\text { activi- } \\
\text { ties }\end{array}$ & $\begin{array}{l}\text { Young } \\
\text { speaker- } \\
\text { young } \\
\text { speaker }\end{array}$ & $\sqrt{ }$ & - & - & - & - & $\begin{array}{c}\mathrm{CJL}+\mathrm{FJ} \\
\mathrm{L}+\mathrm{IL} \\
+\mathrm{FL}\end{array}$ \\
\hline & & $\begin{array}{l}\text { Young } \\
\text { speaker- } \\
\text { Elder } \\
\text { speaker }\end{array}$ & $\sqrt{ }$ & - & $\sqrt{ }$ & - & - & $\begin{array}{c}\text { CJL+ } \\
\text { IL, FJL+ } \\
\quad \text { IL }\end{array}$ \\
\hline & & $\begin{array}{l}\text { Elder } \\
\text { speaker- } \\
\text { Elder } \\
\text { speaker }\end{array}$ & $\sqrt{ }$ & - & - & - & - & \\
\hline & & $\begin{array}{l}\text { Low } \\
\text { education } \\
\text {-High } \\
\text { education }\end{array}$ & $\sqrt{ }$ & - & $\sqrt{ }$ & - & - & \\
\hline
\end{tabular}




\begin{tabular}{|c|c|c|c|c|c|c|c|c|}
\hline \multirow{5}{*}{ Area } & \multirow{5}{*}{$\begin{array}{l}\text { Sub- } \\
\text { domain }\end{array}$} & \multirow{3}{*}{$\begin{array}{c}\text { P-MT } \\
\text { Based on } \\
\text { Age and } \\
\text { Education } \\
\text { Level }\end{array}$} & \multicolumn{6}{|c|}{ Code Choices } \\
\hline & & & \multicolumn{3}{|c|}{$J L$} & \multirow[b]{2}{*}{$\begin{array}{l}I \\
L\end{array}$} & \multirow[b]{2}{*}{$\begin{array}{l}F \\
L\end{array}$} & \multirow[b]{2}{*}{$C M$} \\
\hline & & & $\begin{array}{c}C J \\
L\end{array}$ & $\begin{array}{c}F J \\
L\end{array}$ & $\begin{array}{c}C J \\
L \\
+ \\
F J \\
L\end{array}$ & & & \\
\hline & & $\begin{array}{l}\text { High } \\
\text { education } \\
\text {-High } \\
\text { education }\end{array}$ & $\sqrt{ }$ & - & - & - & - & $\begin{array}{c}\mathrm{CJL}+\mathrm{FJ} \\
\mathrm{L}+\mathrm{IL}+ \\
\mathrm{FL}\end{array}$ \\
\hline & & $\begin{array}{l}\text { Low } \\
\text { education } \\
\text {-Low } \\
\text { education }\end{array}$ & - & - & - & - & - & $\begin{array}{c}\mathrm{CJL}+ \\
\mathrm{IL}, \\
\mathrm{CJL}+\mathrm{FL}\end{array}$ \\
\hline
\end{tabular}

JL : Javanese language CJL: casual Javanese language FJL: formal Javanese language IL : Indonesian language FL : foreign languageactions

TABLE II. The PATterns OF CODE CHOICES IN GOSSIPPING AMONG UJW IN SOCIAL INTERACTIONS

\begin{tabular}{|c|c|c|c|c|c|c|c|c|}
\hline \multirow[b]{3}{*}{ Area } & \multirow[b]{3}{*}{$\begin{array}{c}\text { Sub- } \\
\text { domain }\end{array}$} & \multirow{3}{*}{$\begin{array}{c}\text { P-MT } \\
\text { Based on } \\
\text { Age and } \\
\text { Education } \\
\text { Level }\end{array}$} & \multicolumn{6}{|c|}{ Code Choices } \\
\hline & & & \multicolumn{3}{|c|}{$J L$} & \multirow[b]{2}{*}{$\begin{array}{l}I \\
L\end{array}$} & \multirow[b]{2}{*}{$\begin{array}{l}\boldsymbol{F} \\
\boldsymbol{L}\end{array}$} & \multirow[b]{2}{*}{$C M$} \\
\hline & & & $\begin{array}{c}C J \\
L\end{array}$ & $\begin{array}{c}F J \\
L\end{array}$ & $\begin{array}{c}C J \\
L \\
+ \\
F J \\
L\end{array}$ & & & \\
\hline \multirow[t]{7}{*}{$\begin{array}{l}\text { Ur- } \\
\text { ban } \\
\text { area }\end{array}$} & \multirow[t]{6}{*}{ Rewang } & $\begin{array}{l}\text { Young } \\
\text { speaker- } \\
\text { young } \\
\text { speaker }\end{array}$ & $\sqrt{ }$ & - & - & - & - & CJL+IL \\
\hline & & $\begin{array}{l}\text { Young } \\
\text { speaker- } \\
\text { Elder } \\
\text { speaker }\end{array}$ & - & - & $\sqrt{ }$ & - & - & $\begin{array}{c}\mathrm{CJL}+\mathrm{FJ} \\
\mathrm{L}+\mathrm{IL}\end{array}$ \\
\hline & & $\begin{array}{l}\text { Elder } \\
\text { speaker- } \\
\text { Elder } \\
\text { speaker }\end{array}$ & $\sqrt{ }$ & - & - & - & - & \\
\hline & & $\begin{array}{l}\text { Low } \\
\text { education } \\
\text {-High } \\
\text { education }\end{array}$ & - & - & - & - & - & $\begin{array}{c}\text { CJL+ } \\
\text { IL, } \\
\text { CJL+FJ } \\
\text { L+ IL, } \\
\text { CJL+FJ } \\
\text { L+ IL + } \\
\text { FL } \\
\end{array}$ \\
\hline & & $\begin{array}{l}\text { High } \\
\text { education } \\
\text {-High } \\
\text { education }\end{array}$ & - & - & $\sqrt{ }$ & - & - & \\
\hline & & $\begin{array}{l}\text { Low } \\
\text { education } \\
\text {-Low } \\
\text { education }\end{array}$ & $\sqrt{ }$ & - & - & - & - & $\begin{array}{c}\text { CJL+ } \\
\text { IL, } \\
\text { CJL+ IL } \\
+ \text { FL }\end{array}$ \\
\hline & Arisan & $\begin{array}{l}\text { Young } \\
\text { speaker- } \\
\text { young } \\
\text { speaker }\end{array}$ & $\sqrt{ }$ & - & - & - & - & $\begin{array}{c}\text { FJL+ IL, } \\
\text { CJL+ } \\
\text { IL, } \\
\text { CJL+FJ } \\
\text { L+ IL, } \\
\text { CJL+FJ } \\
\text { L+ IL + } \\
\text { FL }\end{array}$ \\
\hline
\end{tabular}

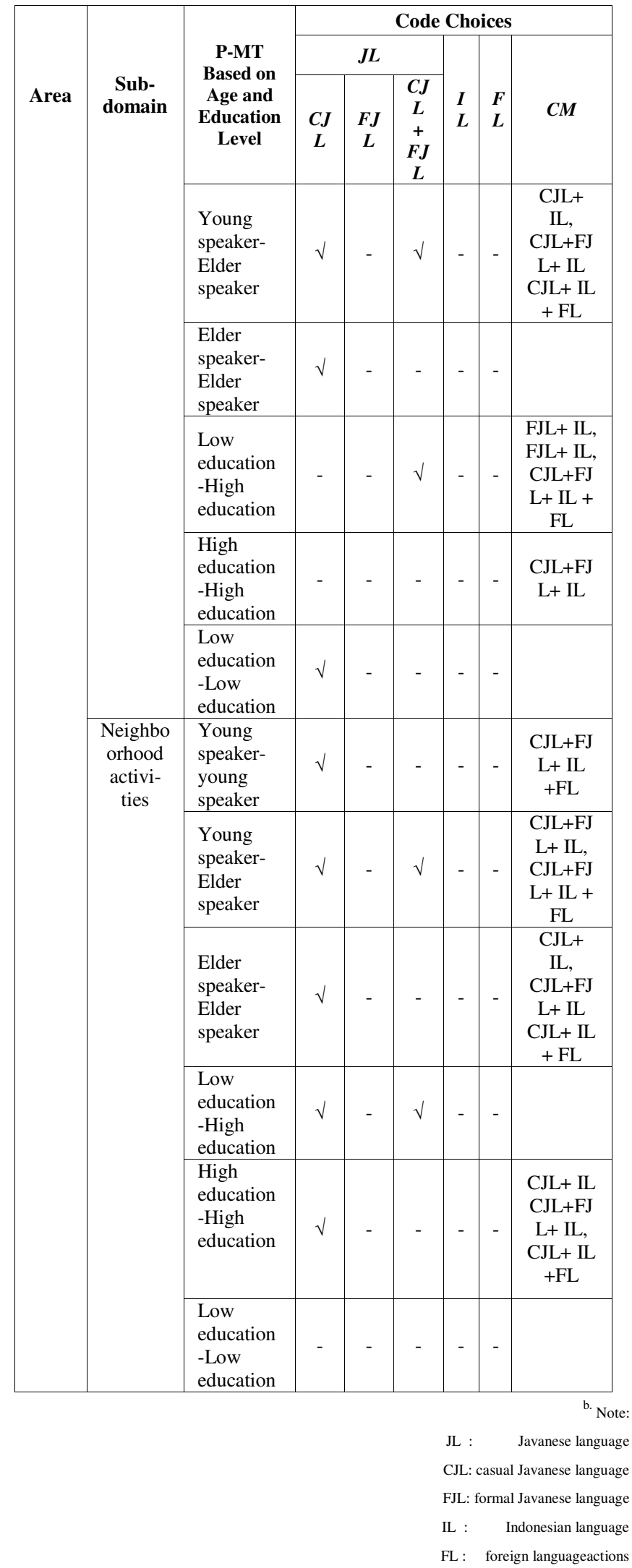

Table 1 shows that the code choice patterns used by JW during gossiping in the social interaction of rewang, arisan, and neighborhood activities are inseparable from the 
accompanying background. JW who live in the countryside are different from those who live in urban areas. Young and highly educated JW employ different code choices, compared to those used by old and lowly educated JW, and vice versa. CJL codes tend to be used by old or young and lowly educated RJWs. CJL + FJL tend to be used in conversation between young and elder RJW with low education and between young RJW with high education. The combination of CJL + FJL + IL tends to be used by younger, highly educated RJW, or vice versa, and by young, highly educated RJW. The combination of CJL + IL + FL tends to be used by young and highly educated RJW. Meanwhile, the codes used by the old or young and highly educated UJW tend to be varied nd this group of UJW are very productive in performing CM. Hereunder are some examples of supporting data showing the patterns of gossiping codes by RJW-UJW in social interaction.

\section{P-MT between Elder Speakers with Low Education}

Context: The gossiping topic is on the neighboring activities of the rich who are not aware of Qurban. P and MT are old and lowly educated.

$\mathrm{P} \quad$ : "Lha kok ora ngewangi ngiris-iris iwak qurban na desamu po ra ana sing kurban?"

MT : "Nggonku ki sing kurban ora kaya wong kene. Nggonku desa gedhe sakmana kae sing qurban paling bur wedhus loro. Akeh wong sugih ning padha durung sadhar gunane qurban."

$\mathrm{P} \quad$ : "Wong nggonmu rak omahe apik-apir tur jembarjembar masak ya dha ra qurban? Kebangeten temen."

Translation

P : 'Why don't you help the people to slice meat of Qurban? Isn't there any such event?'

MT : 'In my hometown, the people do not conduct qurban, as what people here do. My village is big, yet perhaps only two people care about qurban. They sacrifice two goats. Many of the rich are not aware of how important Qurban is.'

$\mathrm{P} \quad$ : 'Many of your neighboors have big fine house. Are you sure none of them care about qurban? That has crossed the line.'

As seen from the data, RJW tend to choose CJL code in their neighborhood activity. This happens because the age and social status among interlocutors are not much different. In addition, factors related to their habit and close intimacy create more comfort for them to use the code.

P-MT between Young and Elder Group with High Education

Context: The talk occurred during a social gathering. $\mathrm{P}$ and MT were gossiping about arisan members who had not made arisan payment.
$\mathrm{P} \quad$ : "Ingkang dereng mbayar kirang lima, Bu Parjo, Bu Noto, Bu Yanto, Mbak Indah kaliyan Bu Fajar. O ya, Bu Puji nggih dereng setor njih?"

MT : "Bu Puji kula telpon mboten diangkat. Bu Puji paling nggak hadir. Kami meski bertetangga dekat, untuk urusan seperti ini ya urusannya masing-masing. Kalau nitip ya dibawa, kalau tidak ya tidak nanya. Tadi ya saya tahu kalau mo tindak, karena tidak bilang nitip ya saya diam saja."

Translation:

MT1: 'There are five members who have not made the payment, including Mrs. Parjo, Mrs. Noto, Mrs. Yanto, Sister Indah, and Mrs. Fajar. Also, Mrs. Puji has not made the payment as well'

MT4: 'I have phoned Mrs. Puji, but she didn't pick it up. It seemed that Mrs. Puji was absent. Although we are close neighboors, we just mind our own business when it deals with such matter. Each of us will forward the payment only when asked to do so. Therefore, I know that she will be away. Because she says nothing about arisan, I just remain silent'

The choices of gossiping codes used by UJW in the above data are comprised of FJL + IL. The words and phrases in bold indicate the choices of gossiping code which rely on IL. As for the other words and sentences, the FJL code option is operative. The choices of FJL code are used by $\mathrm{P}$ because she tries to respect MT who is elder than her. Code mixing between CJL and FJL with some inclusion of IL is very productively used by UJW in everyday communication.

\section{Acknowledgment}

This paper is small part of a dissertation scheme funded by The Ministry of Research, Technology, and Higher Education. We express our gratitude to Universitas Negeri Semarang (UNNES), which has facilitated and provided assistance for the completion of this dissertation.

\section{References}

Alagappar, PM., Dealwis, C., David, M.K. (2018). The influence of age cohorts and social networks on the language choices of the non-indigeous Tamil minority in Kuching, Sarawak, Malaysia. KEMANUSIAAN the Asian Journal of Humanities, 25(1), 69-93.

Chuchu, F., \& Noorashid, N. (2015). Code choice within intercultural communication among ethnic minority in Brunei. Indonesian Journal of Applied Linguistics, 5(1), 86-94.

Crystal, David. (1987). The Cambridge encyclopedia of language. Cambridge: Cambridge Universit Press.

da Silva, A. M. (2017). Exploring the language choice of the non-commercial signs in Jakarta. Indonesian Journal of Applied Linguistics, 7(2), 467-475.

Holmes. (2001). An introduction to sociolinguistics. Second edition. London: Longman Group UK Ltd.

Hudson, R.A. (1996). Sociolinguistics (second edition). Cambridge: Cambridge University Press. 
Kridalaksana, H. (2008). Kamus Linguistik. Jakarta: PT Gramedia.

Mahsun. (2007). Metode Penelitian Bahasa: Tahapan Strategi, Metode, dan Tekniknya. Jakarta: PT Raja Grafindo Persada.

Jaafar, M. F., Awal, N. M., Mis, M. A., \& Lateh, N. (2016). The patterns of language choice at the border of Malaysia-Thailand. Indonesian Journal of Applied Linguistics, 5(2), 176-185.

Sumarsono. (2014). Sosiolinguistik.Yogyakarta: Sabda.

Sutopo, H.B. (2006). Metodologi penelitian kualitatif: dasar teori dan terapannya dalam penelitian. Surakarta: Sebelas Maret University Press.
Wardhaugh, Ronald. (1986). An introduction to sociolinguistics. New York: Basil Blackwell

\section{ABOUT THE AUTHOR}

Prembayun Miji Lestari is a lecturer at Universitas Negeri Semarang (UNNES) and currently is doctorate student in Linguistics Program, Universitas Sebelas Maret Surakarta (UNS).

Djatmika, Sumarlam are Professor in Linguistics Program and a lecturer in the Faculty of Humanities, Universitas Sebelas Maret Surakarta.

Dwi Purnanto is senior lecturer in the Faculty of Humanities, Universitas Sebelas Maret Surakarta. 